\title{
YOUTH, PROTEST AND THE 2014 NATIONAL ELECTIONS: The Case of Zamdela, Sasolburg
}

\section{Mahlatse Rampedi}

Mahlatse Rampedi is a researcher at the

Public Affairs Research Institute, University of the Witwatersrand email: mahlatser@pari.org.za

\begin{abstract}
There is a general perception that youth are apathetic to local politics and national elections. At the same time, young people are often at the forefront of protest. Both electoral politics and protest are forms of political participation; however, the relationship between the two is under-explored. In Zamdela, young people were politicised by two events: the January 2013 protest, and the formation of the Economic Freedom Fighters (EFF) in mid-2014. In addition, many youth are simply conflicted by the lack of service delivery by the ruling party and the lack of viable alternatives in elections. Using qualitative data, this article traces and thematically analyses the political attitudes of youth in Zamdela between the demarcation protest of January 2013 and the May 2014 national elections. Quantitatively, the article provides practical data describing the way in which young people engaged with the 2014 national elections, given the fluctuating perspectives throughout 2013 and 2014. Against this background the article analyses the notion of youth apathy towards politics and elections, as well as Booysen's (2007) 'ballot and the brick' analysis of political engagement, protest and elections. The article demonstrates that a high proportion of young people are politically aware, participated in the protest, voted in elections, and evinced an increased likelihood of voting for parties other than the ANC.
\end{abstract}

Keywords: youth, protest, political participation, elections, political apathy, political alternatives 


\section{INTRODUCTION}

Youth, protest, and voting are common topics of discussion in South Africa. The connection between the three is significant; however, this connection is seldom discussed. There is a widespread impression that youth are apathetic towards politics, and this impacts on the understanding of their participation in political processes such as voting and protests (Mattes, 2008). Thus far, youth in South Africa have the lowest level of engagement in elections of any age cohort. This is evident in the low rate of voter registrations, where only $23 \%$ of eligible $18-19$ year olds in South Africa's 2009 national elections registered to vote, and again in 2014 where only 22\% of them registered (Schulz-Herzenberg \& Southall 2014). This data provides an indication of youth participation in elections but it does not provide a detailed understanding or analysis of the processes that compel youth to either vote or abstain, or how protest action influences their voting.

This article addresses this gap by analysing youth attitudes towards elections and political parties in one township in the Free State province, Zamdela, which was the site of a large municipal demarcation protest in January 2013. It traces these attitudes throughout four periods: after the January 2013 protest; between November and December 2013 (which incorporates the day of elections registrations); pre-elections in 2014; and post-elections. It also analyses these young people's political perceptions thematically, focusing particularly on the themes of governance, liberation legacy, identification with political parties, and change.

The article also offers a detailed analysis of the post-election results from a survey conducted at the end of May 2014. These results are analysed and compared to those of the exit-poll survey administered by the Centre for Social Change, and data from the Electoral Commission of South Africa, also known as the Independent Electoral Commission (IEC). With these results, it was possible to analyse the way in which young people participated in protest, voter turnout, the support for parties and whether or not the results corroborate Booysen's (2007) 'ballot and the brick' analysis of the relationship between protest and elections.

\section{YOUTH ABSENTION FROM ELECTORAL POLITICS}

Perceptions around youth and electoral politics centre around the idea that young people are apathetic towards politics, that they dismiss politics in the early stages of their lives and only engage with them later on. This is often because young people have fewer reasons to take part in political processes given that the motivations for older people to engage in politics do not yet affect them (Quintelier 2007, p.169). They also abstain because they are more critical of political leadership, are quicker to express disgruntlement, and have very little loyalty towards political parties and representatives (ibid.). Looking at African youth and how they vote in 
elections, Resnick and Casale (2013, p. 1) add that 'younger people tend to be less engaged in formal modes of the democratic process, particularly voting'. They often find themselves in an environment where political participation can take many forms; usually unconventional forms that often include 'local community actions, political consumerism, new social movements and activities, single-issue politics and protest actions' (Quintelier 2007, p. 165; Cornwall 2002). Indeed, in the South African context, Mattes (2012) has found that young people and particularly 'born frees ${ }^{1}$ are less likely to vote in elections but more likely to take part in community protests.

Susan Booysen has been a leading scholar in the analysis and understanding of the link between voting and other forms of political participation, such as protesting. She argues that given the limitations of formal channels, many citizens use both elections and protest as a way of influencing power relations and achieving more effective delivery of basic services. Communities thus employ a 'dual-action repertoire' in their politics, or the 'ballot and the brick' (Booysen 2007, p. 25). As a result, communities are able to acquire relatively better service delivery while maintaining their loyalties to the ruling party, which in the case of South Africa is the ANC. Though Booysen makes a compelling argument, Alexander (2012) responds that this thesis cannot adequately explain protest action in South Africa since it lacks the evidence to prove that protesters and voters are the same people. Furthermore, as noted by Alexander, many protestors are young people who are generally less likely to vote. This article thus engages with Booysen's 'ballot and the brick' thesis with a focus on the extent to which this theory can be applied to the case of young voters and protestors.

\section{METHODOLOGY}

Both qualitative and quantitative methods were used to gather data, the latter effectively adding depth to the former. Semi-structured interviews were conducted in March 2013, November and December 2013, and May 2014. The sample included 16 purposively selected young people, 9 men and 7 women, who were between the ages of 18 and 392, an extended segment of what is usually known as youth. Pseudonyms were used for direct quotations. The qualitative data was

1 The generation born after a country's transition to democracy, which in the South African context refers to those born on or after 1994.

2 I purposely selected this age group given the composition of youth political structures in Zamdela. Although the de jure age restriction in the ANCYL is 18 to 25 for members, in practice the age groups are slightly higher. Due to social connections, members do not completely break away from the structures so they often remain active, giving informal direction and campaigning even when they are closer to the age of 40. They therefore make a significant part of the youth cohort that was important to include. Those younger than 18 also make part of this cohort; however they were excluded on ethical grounds and because they are not eligible to vote. 
then analysed thematically, using the themes governance, liberation legacy, identification with political parties, and change. These themes were drawn from the work of Paret (2016) and adapted for this study.

Two sources of quantitative data were used to supplement the qualitative: the exit poll survey conducted on elections day, and a post-elections survey conducted four weeks later. Researchers at the University of Johannesburg's Centre for Social Change, including the author, conducted the exit poll survey. With convenience sampling, 3782 respondents aged between 18 and 85 (National Youth Development Agency, 2017) in the wider sample took part; however only the findings particular to Zamdela were included in this article.

The purpose of the post-election survey was to provide a more detailed focus on the voting patterns of young people aged between 18 and 39, and to triangulate findings from the qualitative data. The sample was selected purposefully, with 258 respondents, 146 men and 112 women, who reside in the sections where the protest was most concentrated. This was in order to make a stronger argument about the relationship between protest and elections.

\section{ZAMDELA'S BACKGROUND}

Zamdela is a township adjacent to the town of Sasolburg in the northern Free State. South African Synthetic Oil Limited (SASOL), a major petroleum and synthetic fuels firm, established Zamdela in 1954 to accommodate employees of its nearby firms (Vaal Triangle Info, 2013). The township sits in the Metsimaholo municipality whose demographics include a population of 90000 , with only 30000 people employed. Figures provided by the South African Institute of Race Relations (SAIRR) show that $42 \%$ of the residents are impoverished and $18 \%$ live in informal settlements (SAIRR 2013). Like many South African townships, Zamdela has become a place where issues of service delivery confront the community, and growing discontent with local government has led to large and sometimes violent protests.

The restructuring of municipal boundaries is a highly contested matter in the Metsimaholo municipality. Due to the lack of communication between the Municipal Demarcation Board (MDB) and the communities, the restriction of municipal borders caused a rift between the government and the community. Much of the blame was apportioned to the mayor, the premier, and the local municipality. On 22 January 2013, after a meeting involving about 10000 people, the community of Zamdela took to the streets for three days in violent protest to stop the planned amalgamation of the Metsimaholo and Ngwathe municipalities. It was commonly perceived that the Parys ${ }^{3}$-based Ngwathe municipality is poorly

3 Parys, a neighbouring town on the banks of the Vaal River. 
funded and has corrupt officials, making the amalgamation unfavourable (Sunday Times 2013). At least 5000 community members took part in the protest, about 200 people were arrested, many shops were looted and destroyed, a number of protesters and police officers were injured, four protesters died, and the losses totalled millions of rands (Marinovich \& Lekgowa 2013). Media reports show that youth played a central role in carrying out of the protest in Zamdela (City Press 2013).

\section{FROM PROTEST TO NATIONAL ELECTIONS: PERCEPTIONS AND ATTITUDES OF ZAMDELA'S YOUTH TOWARDS ELECTIONS AND POLITICAL PARTIES}

Young people's attitudes towards elections are analysed using four themes: governance, liberation legacy, democratic duty, and change. These themes are developed from Paret's (2016) analysis of the Social Change Exit Poll survey results, developed here in relation to both the qualitative and quantitative data presented. Governance describes discontent of the people in terms of the provision of services over time, as well as corruption and leadership, whilst liberation legacy almost exclusively entails the hegemonic power that the ANC wields in its position as the harbinger of freedom in South Africa's recent political history (Paret 2016). Identification refers to people aligning themselves with political parties because of their familiarity with the party or their leaders, which becomes the basis of their support. This is where voters 'identify the ANC as the heroic party that fought for them against the apartheid government and helped them to recover their rights, freedoms and personal dignity' (Beresford 2012, p. 866). Democratic duty entails youth expressing voting as a democratic duty that they, and citizens in the country, should fulfil regardless of their political affiliation. Lastly, change is the theme often cited by a considerable number of people that vote for parties in opposition to the ANC. This term lacks a specific definition. However, in this article the closest definition is changing the ANC as the ruling party.

\section{Attitudes towards governance and the ANC: after the January 2013 protest}

After January 2013 the issue of governance was heavily criticised by youth and there was widespread protest. The ANC's leaders became unpopular and the executive mayor ${ }^{4}$ at the time, Brutus Mahlaku, and premier, Ace Magashule, came under fire. On the one hand, people spoke out vociferously against the

4 The executive mayor chairs the mayoral committee. 
ANC leadership. Some, such as Samuel (30, male, unemployed) a member of the African National Congress Youth League (ANCYL), criticised the ruling party's leadership openly:

The ANC is not failing us; we are being failed by the leaders here. They are very corrupt and are looking at their own pockets. They do not represent what the people want or even what the ANC wants. So as long as Brutus Mahlaku [Executive Mayor] is here, they will keep disappointing us.

On the other hand, people expressed their discontent in other and more unconventional and disruptive ways. The township itself was, for a while after the protest, bombarded with graffiti on walls and on several shack dwellings declaring 'fuck Ace Makgosha's. The protest had made the ANC infamous in the view of many of the residents as well as those people closely linked to it through the local ANCYL.

There were mixed perceptions about the elections and the ANC during this period. A critique of governance and leadership was juxtaposed with a loyalty to the ANC that stems from the liberation struggle and which many young people seem to value. In his analysis of the 2014 national election, Paret (2016) argues that the ANC's support is encapsulated in the liberation legacy with which many black South Africans are familiar. It 'continues to reap a significant "liberation dividend", due to its role as the hegemonic leader of the national liberation struggle' that has subsequently led to what the South African government is today (Paret 2016, p. 442). Therefore, for some people, a sense of both political legacy and identification lingered. Some argued that 'when I was growing up, the only party that I knew was the ANC. It was the party that fought for us and brought us freedom' (Sandile, 37, male, unemployed). Samuel (30, male, unemployed) argued as well that even though there is tension between the community and the ANC, 'I will support it as long as I am still alive. I can proudly say that I am black, green and gold'. The legacy appears to be very important, and many express this as a large part of their motivation for voting, particularly for the ANC. This effectively caused a stalemate between the protest against the ANC and voting for it as the 'ballot and the brick' would have it. The political environment, however, had not changed significantly at this time.

5 This is a play on the Premier's name given how closely 'Magashule' and 'Makgosha' sound. Makgosha refers to a prostitute. 


\section{November/December 2013 including registrations}

The politics of Zamdela changed between the January 2013 protest and the 2014 national elections, transformed by the establishment of the Economic Freedom Front (EFF). Their rise simultaneously resulted in the decline of the ANCYL in the township. The EFF became a significant political player in Zamdela, politicising youth and gaining a following. At the same time, the ANCYL broke apart as its leadership either disappeared or defected. Much of the EFF leadership comprised former ANCYL members. Only a few of its members remained, maintaining the last of what had once been a vibrant ANCYL in Zamdela.

The registration weekend of 9-10 November 2013 pulled in many young people; some registered, some simply observed, and others campaigned for their parties and blew their vuvuzelas ${ }^{6}$. Community anger and frustration had subsided and contrary to earlier expressions of political cynicism, youth came in surprisingly high numbers to register. Opinions on voting varied at this period, with some looking closely at the ANC government:

Voting is not necessarily an answer for life. Voting is not important as such, because politics is the thing that many people nowadays don't consider it seriously because of what is happening within the government. Donald (19, male, student)

In this way, inadequate governance from the ANC devalued the elections. Its failure to deliver services demonstrates the failure of electoral process itself.

Voting in this regard has become less significant as a factor in bringing about the delivery of basic services. Protest actions have become favoured as a means to getting a response from the government. Community protests have been on the rise since 2004, amounting to what Alexander (2010) calls the 'rebellion of the poor'.

The formation of the EFF in mid-2013 was a significant factor in altering people's identification with political parties, particularly with the ANC. Julius Malema, a young leader who already had a large following in the ANCYL, led the EFF. This new party designed its manifesto along the lines of the 1955 Freedom Charter crafted by the ANC and its allies. By November 2013, the EFF had gained popularity among the youth in Zamdela. Sehlogo (29, male) argued that:

6 The vuvuzela is a plastic horn that produces a loud monotone note. It is inspired by the Tswana people's kudu horns that were used to summon distant villagers to attend community gatherings. In South Africa, the vuvuzela is most often used recreationally at large crowd gatherings and festivals, predominantly at soccer matches. 
The reason is that this president of EFF has revealed something that I've been interested in for so long. He talked about the policies of the ANC in 1954, the Freedom Charter. It mentioned that the time the ANC became the ruling party there will be greener pastures in terms of land and everything. But now that has happened and the ANC has not done anything about these things. This is why I support the EFF.

Teboho (21, male) added that:

I don't think I can say that this one has better policies but the EFF has caught my eye, but it is difficult to align myself with them. I like their policies. But then I don't think I'm ready yet to join the EFF. But if I were to vote I would vote for the EFF.

The EFF served two purposes with its entry into the elections. It appealed to many disgruntled young people, politicising them particularly with Charterist policies that spoke directly to the redistribution of land and wealth, encapsulated in what they call 'economic freedom'. Secondly, it became a viable alternative in a political environment dominated by the ANC. With the decline of the ANCYL in Zamdela, and very little presence of the official opposition Democratic Alliance (DA), the EFF became the vehicle through which young people in Zamdela mobilised.

Though the EFF gained considerable popularity among youth, the ANC retained some influence in the township, despite the decline of the ANCYL from its previously dominant position. Through campaigns, rallies and speeches, many were reminded of its liberation legacy. Some young people thus embraced the party despite the rise of the EFF. This was endorsed by researcher Mongezi (22, male, student), who opined that:

We all fall under the ANC and I recognise that it has done a lot. Young people today get to go to universities and students like myself who cannot afford education get to study. We have opportunities that our parents don't have.

Kgotso (18, male, unemployed) also argued that he would vote for the ANC since it was the party that his family voted for, stating that 'my parents are my parents; anything good that happened to them I will support. If my parents are free today, then I am free as well'. Even at this stage the liberation legacy of the ANC lingered on, and more importantly, this legacy was transgenerational. 


\section{Pre-elections: May 2014}

The protest had happened over a year ago and the township was buzzing with party banners and pamphlets promoting the elections. Political campaigns had reached their peak and voting stations were open. It was at this time that the ANC demonstrated its might. Towards election day it overshadowed the EFF and other parties through its highly financed political campaigning. Inundated with placards, posters, banners, and a plethora of walls painted in ANC colours to advertise the ANC, many young people had changed their minds about either abstaining from the elections or voting for opposition parties.

Many came to speak about the ANC. 'We are going to vote for the ANC so no EFF for us. We don't want anything to do with the EFF. We know they are there but we don't want anything to do with it', said Mable (35, female, unemployed). Rose (33, female) declared that her support for the ruling party stems from what she adopted from her parents, and would consequently transfer to her own children. She expressed the view that she was going to vote for the ANC 'because it is the party that my parents and my grandparents voted for. We have freedom because of the ANC, and my child as well.' The activities of the DA are still abysmal in this region, and Mable (35, female, unemployed) expressed the view that she 'cannot simply go to the DA without seeing it works'; while Mathapelo (26, female, unemployed) argues that these new parties are just baby parties and they are just nonsense. I don't think they will last so long'. Bandile (32, male, unemployed) concluded in his view of the EFF, DA and other parties that:

All these people are just complainants against the ANC and none of them are talking about what they are offering. Even the DA is always pointing at $\mathrm{ANC}^{\prime}$ 's mistakes and not promising anything better. Even if we know that there are empty promises we don't really care, but we will vote for the ANC.

The liberation legacy had demonstrated two key points. Firstly, it allowed the ANC to retain much of its support from both the older and younger electorate through cross-generational transference of political opinions. Youth value the liberation legacy, and families, rather than individuals, tend to support similar parties. Secondly, this legacy reinforced the doubts held by the young electorate about other political parties. The idea that no other party has governed the country since democratisation in 1994 is still a concern for most young people regardless of how they perceive the ANC's governance. It is in many ways radical to break away from a party that has governed for over 23 years. The continuing strength 
of the liberation legacy was also borne out in the analysis of the election results and two quantitative surveys, demonstrated in the following sections.

National elections: Comparing results of elections in 2009 and 2014

Table 1 compares the results in the 2014 and 2009 national elections. It shows that nationally the ANC faced growing electoral opposition from the EFF and the DA in the Metsimaholo municipality. In South Africa, national and provincial elections are held on the same day. The figures below are all taken from the national elections, so 'Free State' refers to the province's national election results, not the provincial results.

Table 1

National, provincial and municipal results at three voting districts

\begin{tabular}{|c|c|c|c|c|c|c|c|c|}
\hline & \multicolumn{3}{|c|}{2009} & \multicolumn{4}{|c|}{2014} \\
\hline & & ANC & COPE & DA & ANC & COPE & DA & EFF \\
\hline \multirow[t]{2}{*}{ National } & Votes & 11650748 & 1311027 & 2945829 & 11436921 & 123235 & 4091584 & 1169259 \\
\hline & $\%$ & 65.9 & 7.4 & 16.7 & 62.2 & 0.7 & 22.2 & 6.4 \\
\hline \multirow{2}{*}{$\begin{array}{l}\text { Provincial: } \\
\text { Free State }\end{array}$} & Votes & 734688 & 120018 & 119844 & 708720 & 16516 & 164627 & 82674 \\
\hline & $\%$ & 71.1 & 11.6 & 11.6 & 69.9 & 1.6 & 16.2 & 8.2 \\
\hline \multirow{2}{*}{$\begin{array}{l}\text { Municipal: } \\
\text { Metsi- } \\
\text { maholo }\end{array}$} & Votes & 37483 & 4359 & 11214 & 31758 & 318 & 13824 & 5555 \\
\hline & $\%$ & 66.8 & 7.8 & 20.0 & 58.8 & 0.6 & 25.6 & 10.3 \\
\hline \multirow[t]{2}{*}{ Three VDs } & Votes & 3166 & 542 & 38 & 2567 & 34 & 192 & 444 \\
\hline & $\%$ & 79.3 & 13.6 & 0.1 & 73.8 & 0.1 & 5.5 & 12.8 \\
\hline
\end{tabular}

Source: IEC.

In the Free State, the ANC's vote declined from $71.1 \%$ of the total to $69.9 \%$, a drop of just $1.2 \%$; but in the municipality of Metsimaholo, it fell from $66.8 \%$ to $58.8 \%$, a drop of $8.0 \%$. At each level, support for the Democratic Alliance (DA) increased, and support for the Congress of the People (COPE) declined. Given that the EFF was formed only shortly before the elections, it did remarkably well. Interestingly, it obtained a higher proportion of the vote in Metsimaholo, with $10.3 \%$, than it did in the province, $8.2 \%$, or nationally at $6.4 \%$. The EFF gained more support locally, at $12.8 \%$, from the three voting districts (VD) where the protest was concentrated, making the township one of the places that added to the EFF's low national average. As elsewhere, COPE collapsed and the DA improved its position. 
In all three voting districts (VDs), the ANC remained easily the dominant party although their vote moved downwards from $79.3 \%$ to $73.8 \%$.

So yes, the EFF did well, but not by a large margin. The problem however is that official statistics do not reflect age, and analysing election results alone does not allow an assessment of the relationship that may exist between voting and protesting. So in order to overcome this limitation, I corroborated the results with the exit poll data collected by the Centre for Social Change and collected my own data.

\section{4 national election: protest, exit poll results and post-election data}

Table 2 demonstrates the results of the exit poll survey conducted on election day, 5 May 2014. The survey aimed to capture those people who participated in protest over the previous two years at all age levels, from 18 to 73 . Here, only $27 \%$ of the people from all voting districts had participated in protests in the preceding two years. Of course, the number of people involved in protest is very small since the survey included everyone regardless of voting ages.

\section{Table 2}

Protest participation in previous two years (2012-2014)

\begin{tabular}{|l|l|c|c|c|c|c|c|}
\hline \multirow{2}{*}{$\begin{array}{l}\text { Participated in } \\
\text { protest in past } \\
\text { two years }\end{array}$} & \multicolumn{4}{|c|}{ Social change exit poll } & \multicolumn{4}{|c|}{ Post-election survey } \\
\cline { 2 - 8 } & & Number & $\%$ & Number & $\%$ & Number & $\%$ \\
\cline { 2 - 8 } & Yes & 41 & 27 & 70 & 47.9 & 38 & 33.9 \\
\cline { 2 - 8 } & No & 112 & 73 & 76 & 52.1 & 74 & 66.1 \\
\hline Total & & 153 & 100 & 146 & 100 & 112 & 100 \\
\hline
\end{tabular}

Source: Social Change exit poll and post elections survey.

In comparison to the exit poll survey, the demographics in the post-election survey that focuses exclusively on youth are very different, and unsurprisingly so. As in many protests around the country, the participants of the protest were predominantly males. Close to half of the males surveyed participated in the protest, at $47.9 \%$. This is a relatively large number in comparison to the women with only $33.9 \%$, demonstrating that men have a higher propensity to protest than women do.

There was also an even spread of the participants in terms of age. Though the margin was not large, and similarly with the exit poll data, those younger are more likely to have protested in comparison to the older protestors across all age 
bands (see Table 3). The least likely to take part in protest are those aged in their late thirties, showing in particular that the likelihood of participation in protest decreases from the age of 30 years onwards.

Table 3

Protest participation by age across the three VDs

\begin{tabular}{|c|c|c|c|c|c|c|c|}
\hline & \multicolumn{4}{|c|}{ Age band } & \multirow{2}{*}{ Total } \\
\hline & & & $18-24$ & $25-29$ & $30-34$ & $35-39$ & \\
\hline \multirow{4}{*}{$\begin{array}{l}\text { Participated } \\
\text { in protest in } \\
\text { the past two } \\
\text { years }\end{array}$} & \multirow[t]{2}{*}{ Yes } & no. & 38 & 32 & 23 & 15 & 108 \\
\hline & & $\%$ & 35.2 & 29.6 & 21.3 & 13.9 & 42.0 \\
\hline & \multirow[t]{2}{*}{ No } & no. & 49 & 45 & 35 & 20 & 149 \\
\hline & & $\%$ & 32.9 & 30.2 & 23.5 & 13.4 & 58.0 \\
\hline \multirow[t]{2}{*}{ Total } & \multicolumn{2}{|c|}{ no. } & 87 & 77 & 58 & 35 & 257 \\
\hline & \multicolumn{2}{|c|}{$\%$} & 33.9 & 29.9 & 22.6 & 13.6 & 100 \\
\hline
\end{tabular}

Source: Post-elections survey.

In comparison to the exit poll's results, participation in protest by youth is significantly higher. The post elections survey of those between the ages of 18 to 39 shows that at least $42 \%$ of the people that participated in protest also voted. One cannot reach a definite conclusion from this; however, this shows strong evidence that young people are more likely to participate in both protest and elections.

Table 4 demonstrates the proportion of youth that voted in the elections in comparison to older residents.

Table 4

Participation in 2014 elections by age

\begin{tabular}{|c|c|c|c|c|}
\hline \multirow{3}{*}{ Age } & & Under $\mathbf{4 0}$ & Over $\mathbf{4 0}$ & Total \\
\cline { 2 - 5 } & Frequency & 88 & 70 & 158 \\
\cline { 2 - 5 } & $\%$ & 55.7 & 44.3 & 100 \\
\hline
\end{tabular}

Source: Social Change exit poll.

The table shows a higher turnout of youth in the 20014 elections, at $55.7 \%$, demonstrating that more youth participated in these elections in comparison to older residents, at $44.3 \%$. 
Table 5 below shows those participants in the 2014 national elections by age. Out of $254^{7}$ people, $68.5 \%$ voted. Against expectations based on qualitative research, participation in the elections was high. In the interviews, youth appeared cynical and unlikely to vote given the protest, but this was not reflected in the survey. However, as one might predict from registration data confirmed by interviews, the proportion of older youth who voted was greater than the proportion of younger youth, $82.4 \%$, compared to $60.5 \%$ respectively.

Table 5

Participation in 2014 national elections by age group

\begin{tabular}{|c|c|c|c|c|c|c|c|}
\hline & \multicolumn{4}{|c|}{ Age band } & \multirow[b]{2}{*}{ Tota } \\
\hline & & & $18-24$ & $25-29$ & $30-34$ & $35-39$ & \\
\hline \multirow{4}{*}{$\begin{array}{l}\text { Voted } 2014 \\
\text { national } \\
\text { elections }\end{array}$} & \multirow{2}{*}{ Yes } & no. & 52 & 50 & 44 & 28 & 174 \\
\hline & & $\%$ & 60.5 & 65.8 & 75.9 & 82.4 & 68.5 \\
\hline & \multirow{2}{*}{ No } & no. & 34 & 26 & 14 & 6 & 80 \\
\hline & & $\%$ & 39.5 & 44.2 & 24.1 & 17.6 & 31.5 \\
\hline \multirow[t]{2}{*}{ Total } & \multicolumn{2}{|c|}{ no. } & 86 & 76 & 58 & 34 & 254 \\
\hline & \multicolumn{2}{|c|}{$\%$} & 100 & 100 & 100 & 100 & 100 \\
\hline
\end{tabular}

Source: Post-elections survey, 2014.

Table 6

Participation in protest and 2014 national elections

\begin{tabular}{|l|c|c|c|c|c|}
\hline \multicolumn{2}{|c|}{} & \multicolumn{3}{|c|}{ Participation in protest } & \\
\hline \multirow{2}{*}{$\begin{array}{l}\text { Voted in } \\
\text { 2014 national } \\
\text { elections }\end{array}$} & \multirow{2}{*}{ Yes } & no. & 84 & Nos & Total \\
\cline { 2 - 6 } & & $\%$ & 77.8 & 24 & 108 \\
\cline { 2 - 6 } & \multirow{3}{*}{ No } & no. & 24 & 22.2 & 100 \\
\cline { 3 - 6 } & & $\%$ & 30.0 & 56 & 80 \\
\hline
\end{tabular}

Source: Post-elections survey.

Table 6 provides an analysis of the participation, or lack thereof, of young people in both the 2013 protest and the 2014 national elections. The table categorises firstly, those young people that participated in both protest and elections; secondly, those

7 This number is lower than the total number of participants because some declined to answer the question. 
that took part in elections only; thirdly, those who voted and did not protest in 2013; and lastly those who neither protested nor voted. The first category refers to young people who are highly active in political processes locally and nationally, while the second and third describe those who are partially active.

Young people appear to be more political than expected as $77.8 \%$ of them were active in both protest activity and elections, more than those who are only partially active. In comparison to the exit poll's results as well (see Table 2), participation in protest and elections by youth is higher, showing strong evidence in the case of Zamdela that young people are more likely to participate in both protests and elections.

Among the 80 people that did not vote, only 30\% took part in the protest in comparison to the $70 \%$ of those that had abstained from both the political events. Many simply decided to stay at home when both the protests and elections occurred, demonstrating their apathy to these forms of political process. Note however that what is reflected as apathy towards politics is not a definitive conclusion given that there is evidence of other existing spaces of political participation outside of protests and elections. Additionally, there are many young people who did not vote due to administrative barriers such as not having identity documents, not registering, or by showing their rejection of not only politics in general, but the ANC in particular.

\section{Support for parties}

Among those that had taken part in the 2014 elections, there was a slightly higher level of support for the ANC when we include the wider sample (see Table 7). The ANC took home $83.9 \%$ of the votes in the exit poll data, giving it a huge victory over the other parties, which is not widely different from the $73.8 \%$ recorded by the IEC.

Table 7

Parties voted for in 2014 national elections: data from the VDs, IEC and exit poll survey

\begin{tabular}{|l|c|c|}
\hline Political Party & IEC & Exit Poll \\
\hline ANC & 73.8 & 83.9 \\
\hline EFF & 12.8 & 11.2 \\
\hline DA & 5.5 & 2.8 \\
\hline
\end{tabular}

Source: Social Change exit poll and IEC.

In the exit poll, there was slightly less support for the EFF, at $11.2 \%$ of the 
votes. The DA did not do well either, as expected, with only $2.8 \%$ in the wider sample. There is a problem with the sample size of the exit poll data given that its survey size is very small compared with that of the IEC. Despite this, the results of the exit poll data are very similar to that of the IEC in areas around the three voting districts.

When analysed by age, the exit poll, Table 8 , and post-election survey, Table 9 , show similar results. The ANC still takes first place with $77.7 \%$ of votes, followed by EFF that did relatively well as a newcomer at $18.5 \%$, and followed by the DA and other parties with $2.5 \%$ and $1.3 \%$ respectively.

Table 8

Party voted for in 2014 national elections by youth between 18 and 39

\begin{tabular}{|l|c|c|}
\hline Political Party & Number & Percentage \\
\hline ANC & 63 & 77.7 \\
\hline EFF & 15 & 18.5 \\
\hline DA & 2 & 2.5 \\
\hline Other & 1 & 1.3 \\
\hline Total & 81 & 100 \\
\hline
\end{tabular}

Source: Social Change exit poll

The results of the post-elections survey were very similar to those of the IEC for the three VDs considered above (see Table 9). Moreover, they were very similar to the results of the exit poll data.

Table 9

Party voted for in the 2014 national elections (Valid $N=175$ )

\begin{tabular}{|l|c|c|}
\hline Political Party & Number & Percentage \\
\hline ANC & 126 & 72.0 \\
\hline EFF & 29 & 16.6 \\
\hline DA & 3 & 1.7 \\
\hline Other & 4 & 2.3 \\
\hline Refused & 10 & 5.7 \\
\hline Total & 172 & 98.3 \\
\hline Missing & 3 & 1.7 \\
\hline Total & 175 & 100 \\
\hline
\end{tabular}

Source: Post-elections survey, 2014. 
Much like the results of the exit poll, $16.6 \%$ of the post-elections survey voters supported the EFF, slightly more than backed this party in the three VDs that were analysed. The exit poll shows $18.5 \%$ of the votes for the EFF, thus demonstrating a significant similarity to the post-election survey. Thus, in the VDs where the protest had the greatest impact, the ANC secured widespread support, even amongst youth. Nonetheless, in these areas the EFF did relatively well, especially given that it was a new party formed only shortly before the 2014 national elections. The relationship between protesting and voting is discussed below.

\section{Reasons for voting for the EFF and ANC}

Figure 1 (below) represents a thematic outline of the reasons why people voted for the ANC and the EFF, concentrating on liberation legacy and change. It is notable that a large number of people continued to vote for the ANC because of the ANC legacy. At least $41.1 \%$ of the respondents in the sample stated that they would vote for the ANC because 'it brought freedom', or 'because of Nelson Mandela and his legacy'. This continues to provide evidence that many young people still regard the ANC's legacy as an important factor in voting, and the ANC continuous to benefit from it in elections.

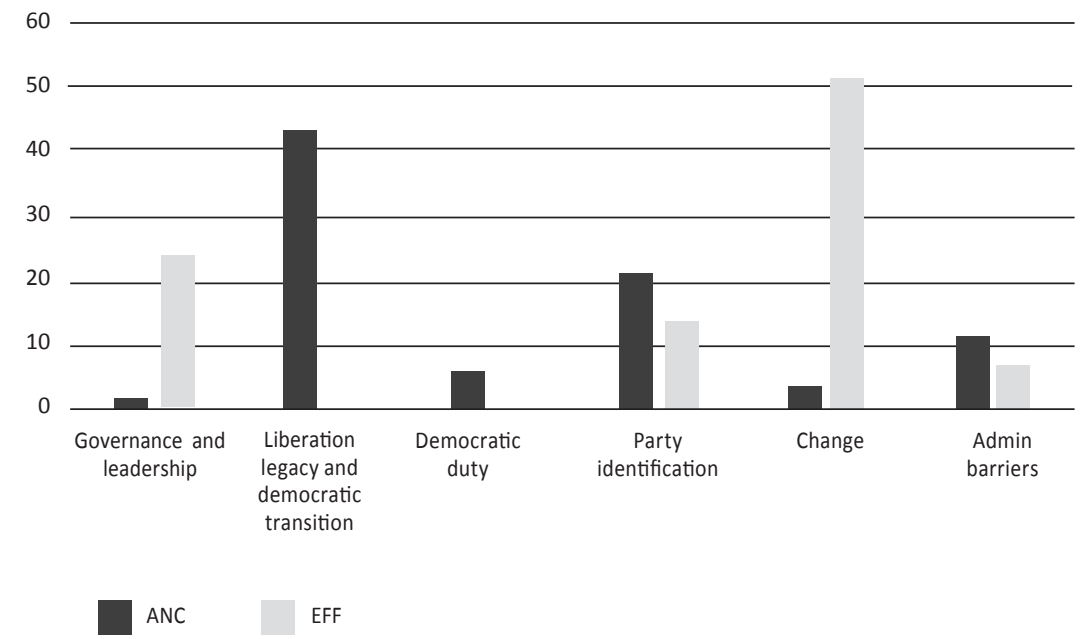

Source: Post-elections survey 2014.

Figure 1

Reasons for voting for ANC and EFF 
Second and supplementary to the theme of liberation is party identification and personalities, and thus the ANC still gains votes because of familiarity. Administrative barriers include only those people that would have voted for the ANC and EFF had they registered or not lost their identity documents.

What is notable are the reasons why young people voted for the EFF. This is where the concept of change makes an appearance. This change is abstract, but here it appears to approximate the change from one party to another, that is a vote not for the ANC. Many of the people that opted to vote for the EFF frequently referred to change, with some saying the same about the DA. Some stated that they voted because the EFF 'will bring change in the future' and that 'Malema stands for change'. With $16.8 \%$ of the total number of people seeking change, young people not only demonstrated dissatisfaction with the ruling party as Paret (2016) elucidated, but also demonstrated that a large pocket of the young electorate considered voting for alternative parties instead of the ANC.

\section{The relationship between Zamdela's protest and the elections turnout}

The relationship between voting and protesting is complex. Booysen (2007) argues that communities use the 'ballot and the brick' in their engagement with the state, using protest to force the ANC government to deliver services, and then voting for the ANC in elections. This implies that the same people who participate in protests also vote for the ANC. My data showed considerable differences from her argument.

Table 10 provides evidence relevant to this debate. Again, it is based on the survey of 18-39 year olds in one township, in the three VDs closest to the protest. The contrast between the ANC and the EFF voters is significant. Only $39.5 \%$ of those who voted for the ANC had protested in the past two years, whereas 73.3\% of those who voted for the EFF protested. That is, young people who voted for the EFF were far more likely to have participated in the protest than people who voted for the ANC. Though there is still significant support for the ANC, the votes that the ANC received are mostly from those people that abstained from protest action in the past two years, which makes up a relatively large $60.5 \%$. Therefore, in the case of Zamdela, the people that do not participate in protest are more likely to vote for the ANC.

Those that protested had a higher rate of support for opposition parties, which in this case is the EFF, and a minimal but still important support for the DA. This shows that young people are not necessarily uncritical of the ANC and can therefore shift to supporting opposition parties. More so, since we are looking at youth, it is interesting that it is they who participated in the protests and subsequently gravitated towards the EFF. The dual-action repertoire therefore 
cannot fully explain the increased rate of protest action parallel to the dominance of the ANC.

Table 10

Participation in protests and voting in elections

\begin{tabular}{|c|c|c|c|c|c|}
\hline & & & \multicolumn{2}{|c|}{$\begin{array}{c}\text { In the last two years, have you } \\
\text { participated in a protest? }\end{array}$} & \multirow[t]{2}{*}{ Total } \\
\hline & & & Yes & No & \\
\hline \multirow{10}{*}{$\begin{array}{l}\text { Party voted } \\
\text { for in } 2014 \\
\text { national } \\
\text { elections. }\end{array}$} & \multirow[t]{2}{*}{ ANC } & votes & 51 & 78 & 129 \\
\hline & & $\%$ & 39.5 & 60.5 & 100 \\
\hline & \multirow[t]{2}{*}{ DA } & votes & 3 & 0 & 3 \\
\hline & & $\%$ & 100 & 0.0 & 100 \\
\hline & \multirow[t]{2}{*}{ EFF } & votes & 22 & 8 & 30 \\
\hline & & $\%$ & 73.3 & 26.7 & 100 \\
\hline & \multirow[t]{2}{*}{ Other } & votes & 2 & 2 & 4 \\
\hline & & $\%$ & 50.0 & 50.0 & 2.4 \\
\hline & \multirow[t]{2}{*}{ Total } & votes & 78 & 88 & 166 \\
\hline & & $\%$ & 47.0 & 53.0 & 100 \\
\hline
\end{tabular}

Source: Post-elections survey 2014

Several reasons can account for the difference between the elections and protest results in this article and Booysen's argument. Since 2006 there have been significant changes in the South African political landscape that have influenced the way in which people vote as well as their parties of choice. Firstly, the socalled 'born frees' were eligible to vote, which is different from the period when Booysen put forward her 'ballot and the brick' thesis. Secondly, the EFF is the first significant party to break from the ANC and shift politically to the left; this is also true of COPE, which was formed just before the elections of 2009 and had also shifted to the left. In 2006, neither the EFF nor COPE existed, so the only significant opposition was the DA. Moreover, for many reasons, and no matter how dissatisfied people were with the ANC, voting for the DA is a big step, which in the minds of many people is not a viable alternative. What we have now in 2014 with the EFF is a viable party that appeals to young working-class people and is therefore considered an alternative to the ANC. 


\section{CONCLUSION}

This case study provides a window on a particular period in time, looking into the attitudes that young people displayed in Zamdela between the protest of January 2013 and the 2014 national elections. Immediately after the protest, many young people were critical of the ANC, the local government, and of ANC leadership. Nonetheless, this criticism was juxtaposed with the loyalty that many young people had towards the $\mathrm{ANC}$, thus maintaining in large part the good standing that the ANC had with its loyal supporters.

Hostility towards the ANC reduced as they campaigned for the national elections in November 2013. At the same time, the EFF was politicising youth and offering an alternative to the hegemonic ANC. It triggered debate and pushed the youth, as well as older people, to take sides, offering them a new set of politics that reduced some of the loyalties that youth had had towards the ANC.

In the third period approaching the elections, the EFF had reached its peak, campaigning and building significant support from young people. It was, however, still overshadowed by the ANC in terms of campaigning budgets, personnel and strategies. In addition, the ANC's liberation legacy, which many youth still value and which is often inherited from and shared with older generations, appeared to retain its importance for some young people.

Booysen (2007) argues that communities use the 'ballot and the brick' in their politics, a dual-action repertoire where communities protest against the ANC to satisfy grievances but vote for it during elections. Although the loyalties towards the ANC remain, new evidence from surveys challenges Booysen's findings. Furthermore, as has been indicated, Alexander (2012) has argued that people who protest are not necessarily the same as those who cast their vote.

The findings here contradict both Booysen's (2007) and Alexander's (2012) results. On the one hand, the elections results demonstrate that a high proportion of young voters had both voted and protested. This refutes Alexander's view that voters are not protesters. On the other hand, and contradicting Booysen's (2007) argument that areas of protest display undented support for the ANC, young people involved in protest were more likely to have voted for an opposition party, disproving her 'ballot and the brick' thesis. When communities want to enhance their capacity to bring about their demands, they will go for the ballot and vote for alternative parties, which in the case of Zamdela was the EFF.

The difference here stems from the changing political environment, with the introduction of the EFF, the decline of COPE, and the lack of DA support in townships such as Zamdela. A combination of protest, the creation of the EFF and the fact that the elections occurred shortly after the protest, politicised the youth. This in turn caused the split between the people supporting the ANC and the EFF. 


\section{- REFERENCES}

Alexander, P 2010. 'Rebellion of the poor: South Africa's service delivery protests-a preliminary analysis', Review of African political economy, vol. 7, pp. 25-40. Alexander, P 2012, 'Barricades, Ballots and Experimentation: Making Sense of the 2011 Local Government Elections with a Social Movement Lens', in CM Dawson \& L Sinwell, (eds), Contesting Transformation: Popular Resistance in 21st Century South Africa, Pluto Press, London.

Beresford, A 2012, 'The Politics of Regenerative Nationalism in South Africa', Journal of Southern African Studies, vol. 38, no. 4, pp. 863-884.

Booysen, S 2007, 'With the ballot and the brick the politics of attaining service delivery', Progress in Development Studies, vol. 7, pp. 21-32.

City Press 2013, 'Cops Monitor Protest-hit Zamdela following Two Deaths', 23 January. Available at http://www.citypress.co.za/news/cops-monitorprotest-hit-zamdela-following-two-deaths/

Cornwall, A 2002, 'Making Spaces, Changing Spaces: Situating Participation in Development', Institute of Development Studies: Working Paper, no. 170, pp. 1-43.

Electoral Commission of South Africa (IEC), 2014. Accessed: 1 July 2014. Available from: http://www.elections.org.za/

Marinovich, G \& Lekgowa, T 2013, Blood, Smoke and Tears: Zamdela Burning. 22 January. Available at http://www.dailymaverick.co.za/article/2013-0123-blood-smoke-and-tears-zamdelas-burning\#.UaMyr9JBNi0.

Mattes, R 2008, 'South Africans' Participation in Local Politics and Government', Transformation: Critical Perspectives on Southern Africa, vol. 66, no.1, pp. 117-141. Mattes, R 2012, 'The 'Born frees': The prospects for generational change in Postapartheid South Africa', Australian Journal of Political Science, vol. 47, no. 1, pp. 133-153.

National Youth Development Agency, 2015. National Youth Policy, 2015-2020.

Paret, M 2016, 'Contested ANC Hegemony in the Urban Townships: Evidence from the 2014 South African Election', African Affairs, vol. 115, no 460, pp. 419-442.

Quintelier, E 2007, 'Differences in political participation between young and old people', Contemporary Politics, vol. 13, pp. 165-180.

Resnick, D \& Casale, D 2013, 'Young populations in young democracies: Generational voting behaviour in sub-Saharan Africa', Democratization, vol. 21, no. 6 , pp. 1-23.

Schulz-Herzenberg, C and Southall R 2014, Elections 2014: The Campaign, Results and Future Prospects, Jacana Media, Johannesburg.

Sunday Times 2013, ‘To hell with Parys'. 27 January. 


\section{Interviews}

Bandile, 23, male, unemployed, interviewed on 20 May 2014 in Zamdela, Free State. Donald, 19, male, student), 03 December 2013, English.

Kenny (32, male, unemployed), 24 January 2013, 08 November 2014, English.

Kgotso (18, male, unemployed), 09 November 2013, English.

Lerato (21, male, unemployed), 09 November 2014, English.

Mable (35, female, unemployed), 03 November 2013, Sesotho.

Mathapelo (26, female, unemployed), 03 November, Sesotho.

Michael (30, male, employed), 09 November 2014, English.

Mongezi (22 male, university student), 04 December 2013, English.

Ndumiso (35, male, partly employed), 28 November 2013, Isizulu.

Rose (33, female, unemployed), 23 may 2014, English and Sesotho.

Samuel (age unknown, male, employment status unknown), 19 March, English.

Sandile (37, male, unemployed), 19 March, English

Sehlogo (29, male, unemployed), 03 December 2013, Sesotho.

Seipati (33, female, unemployed), 23 May 2014, English and Sesotho.

Teboho (21, male, student), 09 November 2013, English. 